\title{
A Critical Assessment of the Policy and Practice of Relocation of Low Income Communities in the City of Colombo
}

By

Neela Piyaseeli Gunasekera

Thesis submitted to the University of Sri Jayewardenepura, Sri Lanka for the award of the Degree of Doctor of Philosophy 


\section{Declaration}

"The work described in this thesis was carried out by me under the supervision of Professor Y.A.D.S. Wanasinghe and I certify that this thesis does not incorporate without acknowledgement any material previously submitted for a degree or diploma in any university or higher educational institution in Sri Lanka or abroad and to the best of my knowledge and belief it does not contain any material previously published or written by another person except where due reference is made in the text"

Nhnased

Neela Piyaseeli Gunasekera

February 2003 


\section{Department of Geography}

University of Sri Jayewardenepura

$26^{\text {th }}$ May, 2003

\section{Certification}

I certify that Mrs. Neela Piyaseeli Gunasekara has incorporated the comments of the Examiners and has revised the Thesis.

I therefore, recommend that this Thesis is suitable for submission for the Ph.D. degree to the University of Sri Jayewardenepura.

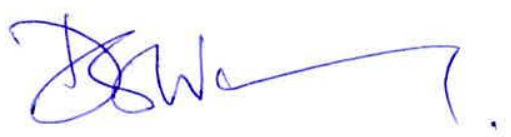

Prof. Y. A. D. S. Wanasinghe Supervisor.

Dept. of Geography,

University of Sri Jayewardenepura

Nugegeda.
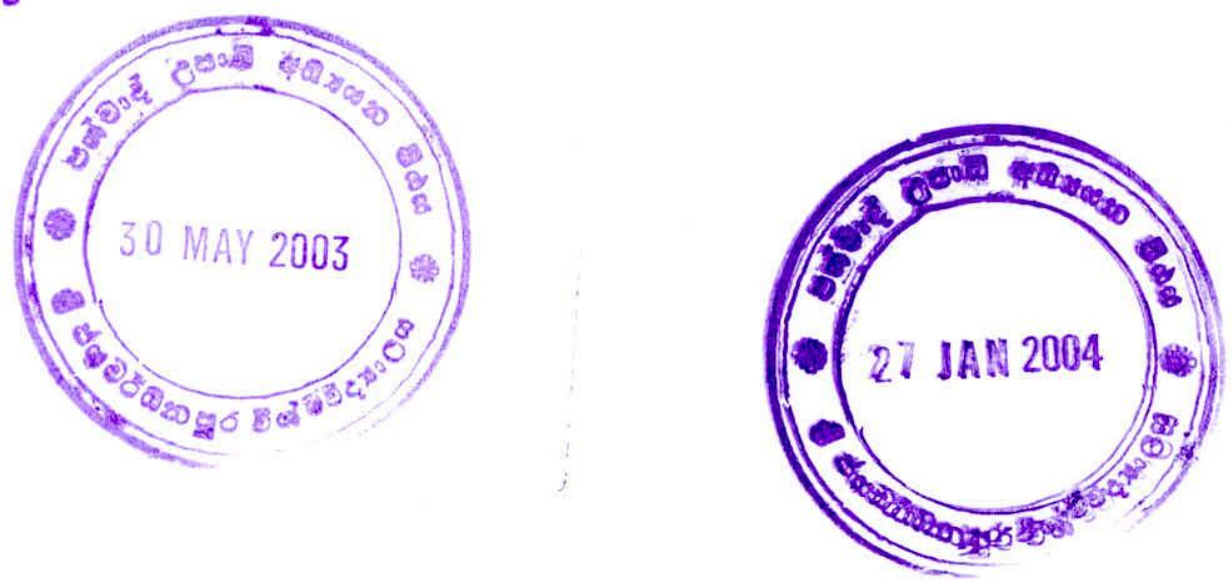


\section{ACKNOWLEDGEMENTS}

I wish to record my gratitude to my Supervisor Professor .Y.A.D.S. Wanasinghe, Department of Geography, University of Sri Jayewardenepura for her valuable guidance and suggestions during the entire study. I am also indebted to Prof. M.M. Karunanayake, Senior Professor of Sri Jayewardenepura University, Dean of the Faculty of Graduate Studies at University of Sri Jayewardenepura, for his constructive comments on the study.

I am very greatful to Prof. M.D.C. Abeyratne, Dr. Sudatta Ranasinghe, Senior Consultant, Postgraduate Institute of Management, Sri Jayewardenepura University, Dr. Jayanthi de Silva Associate Prof. University of Colombo, Mr. Susil Sirivardana, Former Chairman, National Housing Development Authority, Prof. Willie Mendis, Senior Professor, University of Moratuwa and former President, Institute of Town Planners Sri Lanka, Dr. Krishan Deheragoda Chairman, Real Estate Exchange (Pvt) Ltd. Mr. M.A.P. Senanayaka, Senior Lecturer University of Moratuwa, Mr. Lalith Mirihagalle, Executive Director, Real Estate Exchange (Pvt) Ltd. Professor Sarath Kotagama, Environmental Department, University of Colombo and Mr. Nimal Gunatilake, Lecturer, University of Colombo for their valuable comments in the study.

I wish to place on record my sincere thanks to Mr. Suresh and Vijaya Kumar of Housing and Urban Development Corporation Ltd. (HUDCO) New Delhi, Prof. Bahadur from New Delhi, Dr. Bhatiya from Ahamadbad - India, Miss. Ruwani Jayawardena, Social Development Specialist, ADB Manila, Philippnes and Mrs. Merlinda C. Amba, Chief Engineer, National Housing Authority of Manila, Philippines who have contributed to make this study a success

I appreciate the assistance given to me in carrying out the field surveys by officials of the National Housing Development Authority (NHDA) more particularly Mr. Gaminie Vithana, Senior Manager (Colombo City) and Miss. Renuka Munasinghe, Technical Officer.

I owe my gratitude to my husband Hubert and children Indunil, Lakmal and Chaturi for enduring the disorder at home during my studies on the one hand and their courage and sacrifice in covering up my domestic obligations on the other.

I mention with gratitude and appreciation the assistance given by Mr. Motha Britto in carefully reading the script. I am grateful to Mrs. Nirani Perera, Mrs. Chitra Jayaratna and Mrs. Geetha Dorawake for the secretarial work and assisting me on the computer. Finally my gratitude is due to the communities of Navagampura Stage II, Aramaya Place - Dematagoda, 117 Watta - Narahenpita and Sahaspura - Borella for their immense cooperation given to me by discussing with me about their numerous problems.

Finally I express my very sincere thanks to those who helped me in various ways without whose help this research would not have been made possible. 


\section{LIST OF CONTENTS}

List of tables

VII

List of figures

IX

List of photographs

XI

List of annexure

XII

Abbreviations

IX

\section{Chapter 1 Introduction}

1.0 Introduction 1

1.1 The living condition of the urban poor 3

1.2 Housing policies 14

1.3 The need for relocation from an Economic Point of view 15

1.4 The significance of the study 15

$\begin{array}{lll}1.5 & \text { Definitions } & 17\end{array}$

1.5.1 Definitions of "Low income communities" $\quad 17$

1.5.2 Definition on "Relocation" 18

1.6 Objectives of the study 19

1.6.1 General objectives of the study 19

$\begin{array}{lll}\text { 1.6.2 Specific objectives } & 19\end{array}$

1.6.3 Delimitation of the study area 20 
$\begin{array}{lll}1.7 & \text { Methodology } & 20\end{array}$

1.7.1 Selection of the sample 22

1.7.2 Collection of primary data 22

$\begin{array}{lll}\text { 1.7.3 Case studies } & 23\end{array}$

1.7.4 Discussions with decision makers 23

1.7.5 Collection of secondary data $\quad 24$

$\begin{array}{lll}1.8 & \text { Previous studies on relocation } & 24\end{array}$

Chapter 2 Government Policies on Urban Low Income Communities in South and South East Asian Countries

$\begin{array}{lll}2.0 & \text { Introduction } & 35\end{array}$

2.1 Government policies adopted in selected developing countries on relocation of low income communities $\quad 39$

2.1.1 Early Eviction $\quad 40$

$\begin{array}{lll}2.2 & \text { Bangladesh } & 41\end{array}$

2.2.1 The existing Policy and Legal Frame

Work for Resettlement 42

2.2.2 Mitigation of Impacts of Development Project and Relocation 42.

2.3 Indonesia 44

$\begin{array}{lll}2.4 & \text { Pakistan } & 48\end{array}$

2.4.1 Impact of relocation $\quad 49$

2.5 The Philippines 50

2.5.1 Existing policy and legal framework for resettlement in the Philippines 51

2.5.2 Impact of relocation $\quad 53$

$\begin{array}{lll}2.6 & \text { Conclusion } & 54\end{array}$ 
Chapter 3 Urbanizations and the Emergence of the Urban Low Income Housing Problem in Sri Lanka

3.0 Introduction

3.1 Urbanization and low income housing problem in Sri Lanka

3.1.2 Urbanization pattern in Sri Lanka

3.1.3 The spatial Distribution of Urban population in Sri Lanka

3.2 The low income housing problem

3.2.1 Definition of Low income communities

3.2.2 The Low income housing problem

3.2.3 The affordability of low income people

3.2.4 Need for state intervention in low income housing

3.2.5 Emergence and growth of squatter settlements in Colombo

3.2.6 The magnitude of the squatter settlements problem 74

\section{Chapter 4 Shelter Policies and Programmes for Low Income Communities in Sri Lanka}

$\begin{array}{lll}4.0 & \text { Introduction } & 80\end{array}$

4.1 Housing in Different settlement Type in Sri Lanka 81

4.1.1 Rural low income settlements $\quad 81$

4.1.2 Village expansion schemes 82

4.1.3 Colonization schemes $\quad 83$

4.1.4 Regularization of encroachments 83 
4.1.5 Urban low income settlements 84

4.1.6 Meeting the demand for housing 85

4.1.7 Early public sector housing programme $\quad 86$

4.1.8 Direct construction housing programme $\quad 87$

4.19 Aided self help housing programme 87

4.1.1 Other programmes for (ASH) low income earners 88

4.2 Change of policies and programmes after $1977 \quad 89$

4.2.1 New policy strategies in $1994 \quad 91$

4.2.2 Sustainability of the urban and rural housing
programme

$\begin{array}{ll}\text { 4.2.3 The new paradigm } & 96\end{array}$

$\begin{array}{ll}\text { 4.2.4 The million houses programme } & 97\end{array}$

4.2.5 Selection of beneficiaries 99

4.2.6 Sub programmes of the million houses programme 99

4.2.7 The Government policies on relocation $\quad 100$

4.2.8 Acts enacted for solving the low income housing problems

4.2.9 Policy and legislative changes in housing policy in Sri Lanka since habitat II

4.2.10 The Changing Role

4.2.11 The Draft Policy Recommendations of the Presidential Task Force on Housing and Urban Development 1998

4.2.12 Major strategies recommended in the Colombo Metropolitan Regional Structural Plan 
Chapter 5 Critical Evaluation of the Implementation of Relocation Policies for Low Income Communities in the City of Colombo

5.0 Introduction

5.1 Physical Environment of Relocated Settlements and its problems

5.2 Background of the Study Area

5.2.1 Nawagampura stage II - Orugodawatta

5.2.2 Aramaya place - Dematogoda

5.2.3 117 Watta relocated project - Narahenpita

5.2.4 Sahaspura - Borella

5.3 Process of Relocation

5.4 Issues in Relocated Programmes

5.4.1 Inadequacy of Community Participation

5.4.2 Selection of unsuitable sites

5.4.3 The small size of land

5.5 Democratic characteristics of relocatees $\quad 160$

5.6 Distance to Work Place 162

5.7 Levels of Education and Foreign Exchange Earners 163

5.8 Indebtedness Income and Expenditure Pattern 166

5.9 Impact of Relocation on Women 169

5.10 Perception of the Current living Condition

5.11 Perception of the Current Environmental Condition by the Community 


\section{Chapter 6 Conclusions and Recommendations}

$\begin{array}{lll}6.0 & \text { Conclusions } & 191\end{array}$

6.1 Objectives of the Study 191

$\begin{array}{lll}6.2 & \text { Research Findings } & 194\end{array}$

6.3 Reduction of Adverse Impacts of Relocation 195

6.4 Key factors of success when relocation is unavailable $\quad 198$

6.5 Recommendations 204

6.5.1 Administrative framework 204

6.5.2 Infrastructure facilities 205

6.5.3 Welfare of the community 206

6.5.4 Special attention to be paid for female headed house holds and disabled persons 206

$\begin{array}{ll}\text { 6.5.5 Periodic monitoring } & 207\end{array}$ 


\section{LIST OF TABLES}

Table No.

Title

Page

1.1 Distribution pattern of low income settlements in Colombo

1.2 Percentage of basic facilities of low income settlements in the city

1.3 Categorization of problems related to services in relocated housing

2.1 Distribution of squatter settlements in South and South East Asian countries

2.2 Population congestion in Asian countries

3.1 Rate of increase in urban population - Sri Lanka

3.2 Share of urban population and total people

in South - Western quadrant

3.3 Growth rate of urban population by climatic zones

3.4 Low income settlement type in the CMR

3.5 Planned public sector investment (72 - 76) (Rs. Million.)

3.6 Child mortality in the city of

Colombo 1913 - 1922

3.7 Population and housing in city of Colombo 1941 (Per acre)

3.8 The spatial distribution of squatter settlements in the City of Colombo - 1986

3.9 Percentage Distribution of Squatter unite by type of Statuary Reservations in Colombo Municipal Council and Dehiwala, Mt. Lavinia Municipal Council areas -1988

4.1 Planned public sector investment $1977-76$ for housing (Rs. Million)

4.2 Cost comparison between the urban and rural housing programme 
4.3 Sub programmes comprising the hundred thousand houses programme (HTHP)

5.1 Land area by settlement type and ownership

5.3 List of relocated settlements in the city of Colombo

5.4 Relocated settlements with over 750 units in the city of Colombo

5.5 No. of families identified for relocation to "Sahaspura"

5.6 Marital stat s of the community in the study area

5.7 Persons per house hold

$5.9 \quad$ Level of education in three study areas

5.10 Foreign exchange earners in the study areas 164

$5.11 \quad$ Indebtedness in the community 166

5.12 Monthly income and expenditure pattern 167

5.13 Relationship between income and expenditure of three study areas

5.14 Squatter population of selected cities in India

5.15 Perception of residents on present living condition of the study area 


\section{LIST OF FIGURES}

Figure No.

Title

Page

1.1 Low income settlements in the city of Colombo

8

1.2 Type of relocated projects in Colombo

10

3.1

Proposed urban clusters in Sri Lanka

60

4.1 Relocation policies : changing approaches

101

4.2 Government responses to low income settlement problem in Sri Lanka

5.1 Density of population by wards in the city of Colombo

Distribution of Under-served settlements in the city of Colombo

5.3 Distribution of Squatter settlements in the city of Colombo

5.4 Distribution of relocated settlements in city of Colombo

5.5 Distribution of low lying lands in Colombo \& suburbs

Colombo North and South Drainage canals 
5.16 Comparison of the environmental conditions of the communities

6.1 Relocation process recommended by the World Bank 199

6.2 Linkages with institutions 202

6.3 Proposed relocation process for Sri Lanka 208

$\begin{array}{lll}6.4 & \text { Proposed monitoring process } & 210\end{array}$

6.5 Field level Monitoring of Resettlement Activities 212

6.6 Identifying income restoration plan 215

$\begin{array}{lll}6.7 & \text { The conceptual plan } & 216\end{array}$ 


\section{LIST OF PHOTOGRAPHS}

No.

Title

Page

5.1 Sahaspura Newly Constructed Housing Project

149

5.2 Stagnation of water - Navagampura Stage II

5.3 The entire lower part of the house is under flood water Navagampura Stage II

5.4 Absence of an adequate drainage system Aramaya Place

Middle class housing and impact of floods - 177 Watta housing project Narahenpita

Utilization of limited space within the two perch plotNavagampura Stage II

Common bathing places - Navagampura Stage II

Multiple use of the Backgarden - Nawagamapura Stage II 158

5.9 The unhealthy environment in the backgarden -

Gnanavimala Mawatha, Dematagoda

The water tanks near the common toilets - Thotalanga

5.11 Inadequacy of garbage collection Facilities -

Navagamapura Stage II

5.13 Mixture of low and high income communities Navagampura Stage II 